\title{
STREAM AS A NEW HYPERMEDIA GENRE
}

\author{
Aleksey V. Bolotnov \\ Tomsk State Pedagogical University, Tomsk, Russia
}

\begin{abstract}
The relevance of the study is due to changes in media culture evoked by new technologies that stimulate the emergence of a new hypertext genre-stylistic reality. The article examines a new media phenomenon stream. The stream is considered as public communicative flow that takes place in real time and includes text, as well as video and audio content, organized by the streamer (the author) - information and media personality with the active involvement of other media participants of different types; it is implemented in live Internet broadcasting; it creates a variety of opportunities for any participant (from commenting, polling, to participation in action). The stream emerged from the instrumental-service approach to the development and comprehension of various relevant topics in the content presentation. The aim of the participants in this media process is self-expression and self-actualization, the incentive to be active and interact (from personal motives to socially significant ones). As a hypermedia genre it is considered on the material of media discourse "\#daiDudya" with the participation of A.A. Venediktov, taking into account his linguistic and extralinguistic characteristics. The study of the stream as a new and insufficiently investigated phenomenon of modern media communication, the development of a methodology for its analysis are of interest for communicative and cognitive linguistics, media linguistics, sociology, psychology, discourse, and cultural linguistics.

Key words: stream, streaming, media communication, speech genre, hypermedia genre.

Citation. Bolotnov A.V. Stream as a New Hypermedia Genre. Vestnik Volgogradskogo gosudarstvennogo universiteta. Seriya 2. Yazykoznanie [Science Journal of Volgograd State University. Linguistics], 2021, vol. 20, no. 2, pp. 111-120. (in Russian). DOI: https://doi.org/10.15688/jvolsu2.2021.2.10
\end{abstract}

УДК $81 ' 1: 004.522$

Дата поступления статьи: 11.01.2021

ББК 81.006 Дата принятия статьи: 11.02.2021

\section{СТРИМ КАК НОВЫЙ ГИПЕРМЕДИАЖАНР}

\section{Алексей Владимирович Болотнов}

Томский государственный педагогический университет, г. Томск, Россия

\begin{abstract}
Аннотация. Актуальность исследования обусловлена изменениями в медиакультуре в связи с новыми технологиями, стимулирующими появление новой гипертекстовой жанрово-стилистической реальности. В статье исследуется недавно возникший медийный феномен - стрим. Он представляет собой открытый коммуникативный поток, существующий в реальном времени, включающий текстовый, видео- и аудиоконтент, организованный информационно-медийной личностью стримера (автора) при активном участии других медийных личностей разных типов; реализуется в прямом интернет-вещании и трансляции, создает многообразие возможностей для любого участника (от комментирования, опроса до соучастия в действии). Стрим возник благодаря инструментально-сервисному подходу к освоению и осмыслению различных актуальных тем в представлении контента. Цель участников этого медиапроцесса - самовыражение и самоактуализация, побуждение к активности и взаимодействию (от личных мотивов до социально значимых). Как гипержанр стрим рассмотрен в лингвистическом и экстралингвистическом аспектах на примере медиадискурса «\#дайДудя» с участием А.А. Венедиктова. Исследование стрима как нового и недостаточно изученноо го феномена современной медиакоммуникации, разработка методики его анализа представляются важными для коммуникативной и когнитивной лингвистики, медиалингвистики, социологии, психологии, дискурсологии, лингвокультурологии.
\end{abstract}

Ключевые слова: стрим, стриминг, медиакоммуникация, речевой жанр, гипермедиажанр. 
Цитирование. Болотнов А. В. Стрим как новый гипермедиажанр // Вестник Волгоградского государственного университета. Серия 2, Языкознание. - 2021. - Т. 20, № 2. - C. 111-120. - DOI: https://doi.org/ 10.15688/jvolsu2.2021.2.10

\section{Введение}

Новые информационные технологии в медиакоммуникации, бурно развивающиеся в современном мире, определяют многообразие медиажанров, которые необходимо изучать. О внимании исследователей к современным медиажанрам и разным аспектам их рассмотрения можно судить по многообразию подходов к данному феномену, реализованных в работах: [Горошко, Полякова, 2015; Давлетшина, 2017; Ковалев, 2016; Корецкий, 2020; Финадеева, 2008; и др.].

Лингвистов интересуют типология медиажанров [Горошко, Полякова, 2015; Ковалев, 2016], их анализ в когнитивном аспекте [Финадеева, 2008], связь с традиционными жанрами [Вольф, 2020; Давлетшина, 2017; Корецкий, 2020], проблемы востребованности медиажанров в современных условиях [Колесниченко, 2019]. Особое внимание обращается на видеоблогинг [Дадаева, Сновальникова, 2019; Лущиков, Терских, 2018a; 2018б; Панюкова, 2018; Текутьева, 2016], который изучается в коммуникативном, культурологическом, социальном, экономическом аспектах. Так, «видеосторителлинг» рассматривают как формат, «удачное совмещение традиционных коммуникативных приемов и современных возможностей компьютерной визуализации» [Панюкова, 2018, с. 122]; видеоблогинг определяют как формат видеоконтента, «который сочетает в себе основные функции телевидения и интернет-пространства» [Лущиков, Терских, 20186, с. 57]; проводится сравнительный анализ «сюжетных особенностей современного аудиовизуального контента как в его телевизионной форме, так и в формате видеоблогов» [Шестерина, 2020, с. 169].

Вместе с тем стрим как новый медиафеномен остается пока недостаточно исследованным, несмотря на интерес к нему специалистов разных областей знания. В имеющихся работах делается акцент на культуре соучастия в игровых стримах [Сергеева, Зиновьева, 2020]; стрим анализируется в социально-политическом аспекте в связи с его ролью в солидаризации общества [Сирмаи, 2019]. В современных исследованиях стрим рассматривается в разных аспектах: социальнокоммуникативном [Болычева, 2018], жанровом (с точки зрения связи с традиционными журналистскими жанрами) [Вольф, 2020], финансово-экономическом (как способ заработка на игровых стримах) [Алимов, 2018].

Относительно природы и сущности стримов есть разные точки зрения. Игровые стримы, например, определяются как «паратекст, на фоне которого формируется оригинальный нарратив стримера, сопровождаемый репликами представителей зрительского сообщества», стримы трактуются «в качестве медийных публичных арен» [Сергеева, Зиновьева, 2020, с. 221]; стрим определяют как «прямой эфир (потоковое видео в реальном времени через мобильные устройства)» [Сирмаи, 2019 , с. 271]. Как одну из «новых форм взаимодействия с аудиторией», «не только как процесс доставки пользователям мультимедийных потоков информации в режиме реального времени, но и в качестве социальнокультурного феномена» рассматривает стрим М.Д. Болычева [Болычева, 2018, с. 159]. В качестве «монетизируемой досуговой практики» трактует игровой стрим А.А. Алимов [Алимов, 2018, с.79]. О.А. Вольф соотносит стрим с традиционным журналистским жанром «прямой эфир» [Вольф, 2020, с. 70].

Таким образом, очевидно многообразие разных точек зрения на данный феномен. Целью статьи является определение статуса стрима как нового в массмедиа явления на основе комплексного подхода к нему и обобщения имеющихся научных данных.

\section{Методика исследования}

В качестве базового метода были использованы дискурс-анализ, а также метод комплексного описания, включающий приемы обобщения, интерпретации и классификации лингвистических и экстралингвистических фактов. В трактовке дискурсанализа нам близка точка зрения В.Е. Чер- 
нявской, которая полагает, что его первый этап включает собственно текстовый анализ, второй - собственно дискурсивный анализ, который «начинается с проецирования на элементы содержательно-смысловой и композиционно-речевой организации текста психологических, национально-культурных, прагматических и др. факторов» [Чернявская, 2003, с.71].

\section{Результаты и обсуждение}

Что такое стрим? Каков его коммуникативный, культурологический и лингвистический статус? Стрим можно определить как открытый коммуникативный поток, существующий в реальном времени, как персональный медиадискурс в действии, организованный личностью стримера при соучастии широкой неконтролируемой аудитории медийных личностей разных типов, чаще всего наблюдателей-комментаторов.

По характеру своего протекания данный коммуникативный поток является свободным, интерактивным, трендовым. В жанровостилевом отношении он определяется модой и индивидуальным стилем организатора, а также выбранной им тематической нишей, характеризуется прямым интернет-вещанием и трансляцией, создает многообразие возможностей для любого участника, который может задавать вопросы, комментировать, соучаствовать в действии.

Стрим возник благодаря инструментально-сервисному подходу к освоению и осмыслению различных актуальных тем в представлении контента. При этом формируется цепочка личных пристрастий и мнений, которая находит свое отражение в коммуникативном потоке. В стриме технологии визуализации и нарративные технологии (сторителлинг, эссеистика, публицистика, очерк и заметки) выходят на первый план. Цель участников этого процесса - самовыражение и самоактуализация, побуждение к активности и взаимодействию (от эгоистических форм до альтруистических и социально значимых) с аудиторией.

В широком смысле это диалоговый гипермедиажанр, сочетающий разные формы спонтанной беседы, в которую вовлекаются участники коммуникативного события на ос- нове прямых трансляций на видеохостингах (Twitch, GoodGame, YouTube и др.).

Стрим возник и функционирует благодаря новым информационным технологиям и использованию специальных инструментов (программных возможностей различных платформ и сервисов: Livestream Vimeo, DaCast, StreamShark и др.). Это живой эфир, в котором каждый обычный человек может участвовать в спонтанной коммуникации со всеми, кто желает присоединиться к общению, кому интересна тема, заданная организатором: путешествия, кулинария, спорт, культура, политика и т. д. По-видимому, желание включиться в действие и соучастие лежит в основе популярности стриминга.

При подходе к стриму как к особой жанровой форме медиадискурса целесообразно рассмотреть его признаки с использованием модели речевого жанра, разработанной Т.В. Шмелевой [Шмелева, 1997]. Модель включает следующие параметры: коммуникативную цель, образ автора, образ адресата, образ прошлого, образ будущего, диктумное (событийное) содержание, языковое воплощение. С этой точки зрения стрим характеризутся тем, что в образе автора (стримера) может выступать любой человек как информационно-медийная личность (см. подробнее о ней: [Болотнов, 2015a, с. 47-51]), готовая к самопрезентации и испытывающая потребность в ней; в роли адресата выступает широкая аудитория пользователей Интернета; коммуникативная цель стрима - выражение участниками себя, своей культуры и картины мира, системы ценностей, различных предпочтений в личных и/или альтруистических целях; образ прошлого связан с предыдущим дискурсом участников как продолжение начатого ранее диалога; образ будущего непредсказуем и зависит от интенций и действий участников; диктумное (событийное) содержание является разнообразным, отражающим тематические предпочтения и реальные действия участников медиакоммуникации; языковой контент стрима отличается многообразием, полидискурсивностью, зависит от типа речевой культуры стримера и участников, их тезауруса и мотивов; наряду с языковым контентом, для стрима обязателен видео- и аудиоконтент, фиксирующий в реальном времени 
соучастие стримера и коллективного адресата. Стрим как гипермедиажанр может включать разные виды информационных, оценочных, перформативных, императивных жанров по типологии Т.В. Шмелевой [Шмелева, 1997].

Стрим, таким образом, можно отнести к открытому диалогическому комплексному гипермедиажанру, который включает, кроме текстового, видео- и аудиоконтент, предполагает реальное соучастие автора и коллективного адресата, обусловлен технологическими возможностями медиа, представлен на специальных платформах и сервисах.

От подкаста стрим отличает, во-первых, живое общение в форме открытого интерактивного диалога, часто развлекательного, в интересах привлечения большой аудитории; во-вторых, функционально-сервисный подход: стрим возможен только благодаря техническим возможностям видеохостингов, платформ и их сервисам. Стриминговая деятельность как модное течение реализуется, например, на YouTube, в социальных сетях (ВКонтакте, Фейсбук, Инстаграм, Одноклассники). Стриминг отражает такие новые тенденции в области виртуального жанроведения, как синкретизм, конвергенция, мультимедийность.

Обратимся к анализу эмпирического материала. Переход к новому гипермедиажанру в режиме реального времени наблюдается, например, в медиадискурсе А.А. Венедиктова «\#дайДудя» (Венедиктов, 2020). Это живое общение журналиста, главного редактора радио «Эхо Москвы», с теми, кто подключается к общению в чате на платформе YouTube. Медиакоммуникация имеет свободный спонтанный характер с использованием разговорных конструкций и лексики разной стилистической маркированности не только в дискурсивных практиках информационномедийных личностей наблюдателей, но и журналиста (о данном типе языковых личностей см.: [Болотнов, 2015a; 2016]).

Функционально-инструментальные возможности платформы YouTube позволяют не только видеть и слышать ведущего, но и видеть все записи чата во время эфира и упорядочивать комментарии, то есть собственно текстовая реальность доступна для изучения.
Наряду с книжной и межстилевой лексикой, в устном дискурсе А.А. Венедиктова в ситуации спонтанного общения используется разговорная и просторечная лексика: порушены (о договорах), улетела (исчезла) (о программе), валите (уходите), латаем (исправляем). Употребляются и разговорные синтаксические конструкции, свойственные свободному неподготовленному общению: $A$ вот смотрите...; А давайте посмотрим...; Вот Волгоград приветствует, Череповец приветствует... Ведущий использует вопросноответные комплексы: Как я могу оценить Зеленского? Его будет трясти... Тяжело ему, тяжело...; Будет ли интервью с Михаилом Горбачевым? Нет...

Характеризуя особенности речи посетителей чата в данном формате, отметим, что их медиадискурс отличается еще большей свободой, включая сниженную лексику (ср.: бухать, уважуха и др.). В дискурсивных практиках, судя по общему чату, представлены разные элементарные речевые жанры: вопросы, предложения, советы, комментарии, оценки. Вопросы задаются на различные темы, как личные, так и социально-политические: Не боитесь коронавируса на «Эхе»?; Bы поститесь?; Комменты читаете после эфиров?; Будет ли интервью с М. Горбачевым?; Как вам политик Шнуров?; Как гарантировать добровольность голосования? и др. Представлены иные жанровые формы (в примерах сохранена авторская орфография и пунктуация): приветствия (Лада Красильникова Технологический институт! От студенток пламенный привет; Саша ДачникАлексей Алексеевич, приветствую из Самары); предложения (Нужна передача, которую вел бы подросток о политике); советы (Денис СорокинВерните Баршевского в эфир!); комментарии (александр че мне кажется “коварный” и есть Алексей Алексеевич); благодарность и оценка (Спасибо за создание такого формата. Вы мой супергерой; Лучшая станциия!).

Что касается медиадискурса ведущего, в общении с посетителями чата он использует прямую и косвенную, реже несобственнопрямую речь. Из элементарных речевых жанров представлены: обращение (Юрий, смотрите...; Минск, спасибо, скоро приеду!); 
ответы на вопросы (Отвечу Алексу. $\mathrm{Mbl}$ не разговаривали о ситуации в стране...); комментарии (Я очень хорошо и прекрасно знаю о дебатах, которые вела Екатерина Шульман и Борис Акунин; Общзююь я с людьми, а это уродыл..); советы (Секрет успешности - быть целеустремленнымм и любопьтнылм); прощание (Всем пока u до новых встреч!); оценки в ответах на вопросы (на вопрос в чате Владислав Погонинваше отношение к Невзорову последовал ответ ведущего: Я с удовольствием его слуиаю. С удовольствием его читаю, когда есть возможность...).

В целом данный формат общения позволил собрать огромное количество участников из разных городов, регионов, стран - тех, кому интересен ведущий (стример). При этом в ходе общения А.А. Венедиктов обращался к звукорежиссеру с репликами, попутно комментируя очередные вопросы из общего чата, то есть общение сопровождалось действиями в режиме реального времени, которые представлены в записи на YouTube.

Сравнение данного медиадискурса журналиста и главного редактора «Эхо Москвы» (Венедиктов, 2020) с другим медиадискурсом, который был спустя несколько месяцев, в январе 2021 г. (Венедиктов, 2021), показало, что число участников общего чата увеличилось, как и число комментариев (с 137 до 180) и просмотров (с 72032 до 83 266). Это позволяет сделать вывод о большой популярности данного формата, что во многом связано с личностью ведущего, выступающего в роли стримера.

Стрим как коммуникативный поток приобрел новую текстовую реальность с доминированием вторичных и третичных текстов как реакций на первичные и вторичные тексты (см. о них: [Болотнов, 2015б]) в связи с подключением новых пользователей к разговору и возвратом к ранее затронутым темам. Об этом можно судить по актуальной для информационно-медийных личностей наблюдателей тематике. Она связана, в частности, с законом, позволившим организовать акцию «Круг добра» после указа президента, о котором сообщил А.А. Венедиктов, начиная интерактивную встречу после Нового года: Вmoрая удача - Путин подписал указ, который позволит получать деньги для детишек, больных тяжельми болезнями.

Другая тема, вызвавшая большой интерес слушателей и зрителей, откликнувшихся на нее серией вопросов и суждений, связана с оценками поведения президентов Д. Трампа, В.В. Путина, М.С. Горбачева, А.Г. Лукашенко: об истинности и ложности их суждений по поводу актуальных событий, о необходимости принимать сложные решения и об ответственности за это. Вместе с тем данная тема в рамках общего медиадискурса поднималась неоднократно на фоне массы других вопросов, не связанных с ней. Стимулом к последующему разговору послужил ответ А.А. Венедиктова на вопрос Bbl уважаете Tpaмna?. Ответ Хороший вопрос. Eсть за что уважать... с аргументацией и продолжением о том, чем Трамп вызвал неуважение: ...он лжец, он не стесняется лгать, говорить неправду - и с конкретным примером этого относительно результатов голосования стимулировал реакцию в общем чате. В третичных текстах (вопросах и суждениях участников) тема была продолжена: $У$ меня спрашивают про уважение к Путину... (далее следует рассуждение и личная оценка журналиста, последующее сравнение с Трампом и возврат к теме поведения президентов в связи с новыми вопросами из чата о Лукашенко и Горбачеве относительно принимаемых ими трудных решений в сложных ситуациях).

Очевидно, слушателей и зрителей привлекла не только тема и искренность журналиста, выступающего в роли стримера, но и его особый взгляд на вещи (ср., например, его суждения: Соврал - это когда лжешь по поводу фактов... Политика - дело гибкое).

Повтор отдельных тем, вызвавших особый интерес участников, отмечается на фоне массы других самых разных вопросов, включая личные (В чем ваши разногласия с Леонидом Парфеновым?; Пользовались ли вы своим положением для себя? и др.), поступающих по мере включения участников в коммуникативный поток.

В жанровом отношении данная медиакоммуникация не слишком отличается от ранее рассмотренного стрима. Здесь используются те же жанры, к которым добавляются некоторые другие, например: приветствия и поздрав- 
ления (Ну что, всем добрый день! Всех поздравляю с праздниками, которые были и будуm!); ответы и комментарии как стримера, так и наблюдателей-свидетелей (Чат - это междусобойчик...); побуждение к действию (Представьте, Вам надо принять решение... Правильное или неправильное...); шутка (на вопрос $A$ Венедиктов хороший человек? следует ответ Венедиктов не хороший человек, а очень хороший человек!); оценка (Очень хороший проект... (о проекте «Мой район» на радио «Эхо Москвы»)) и др.

Таким образом, стрим как новый формат медиакоммуникации приобретает своих сторонников и отражает новые тенденции, связанные с популярностью интерактивного полидискурсивного общения, которое интересно и стримеру, и аудитории.

\section{Заключение}

Внимание к стриму как новому медийному феномену можно объяснить дауншифтингом, усталостью информационно-медийных личностей от виртуальной реальности, желанием включиться в реальное действие, в живое общение благодаря различным технологическим возможностям популярных платформ и сервисов (см. о дауншифтинге в статье: [Москвин, Полуян, Кушова, 2017]).

Стрим может быть рассмотрен как особый формат медиаобщения, как языковой, культурный, коммуникативный, социальный, экономический феномен, отражающий определенный этап общей и речевой культуры современного общества и этап его технологического развития.

Как комплексный гипермедиажанр стрим включает, кроме текстового, видео- и аудиоконтент, предполагает реальное соучастие автора и коллективного адресата, обусловлен технологическими возможностями медиа, представлен на специальных платформах и сервиcax. Языковой контент стрима определяется типом речевой культуры стримера и его коллективного адресата, их информационным тезаурусом, вкусовыми и тематическими предпочтениями, целями и мотивами.

Дальнейшее изучение стриминга и разработка методики его анализа перспективны для коммуникативной и когнитивной лингвистики, медиалингвистики, социологии, психологии, дискурсологии, лингвокультурологии.

\section{СПИСОК ЛИТЕРАТУРЫ}

Алимов А. А., 2018. Как хобби становится в креативной экономике работой // Экономическая социология. T. 19, № 3. C. 79-105. URL: https://cyberleninka.ru/article/n/kak-hobbistanovitsya-v-kreativnoy-ekonomike-rabotoy (дата обращения: 04.01.2021).

Болотнов А. В., 2015а. Текстовая деятельность как отражение коммуникативного и когнитивного стилей информационно-медийной языковой личности. Томск : Изд-во Том. ЦНТИ. $274 \mathrm{c}$.

Болотнов А. В., 2015б. Третичные медиатексты как отражение информационного эха // Вестник Томского государственного педагогического университета. Вып. 6 (156). С. 138-142.

Болотнов А. В., 2016. Информационно-медийная языковая личность наблюдателя (свидетеля) и ее дискурсивные практики // Вестник Томского государственного педагогического университета. Вып. 11 (176). С. 35-41.

Болычева М. Д., 2018. Стриминговое вещание как феномен современной медиасреды // Коммуникология. T. 6, № 4. С. 159-169. URL: https:// cyberleninka.ru/article/n/strimingovoeveschanie-kak-fenomen-sovremennoymediasredy (дата обращения: 04.01.2021).

Вольф О. А., 2020. Традиции журналистских жанров в новых медиа (на примере прямого эфира, рекомендации и эксперимента) // Вестник Хакасского государственного университета им. Н.Ф. Катанова. № 2. С. 68-72. URL: https:/ /cyberleninka.ru/article/n/traditsii-zhurnalistskihzhanrov-v-novyh-media-na-primere-pryamogoefira-rekomendatsii-i-eksperimenta (дата обращения: 04.01.2021).

Горошко Е. И., Полякова Т. Л., 2015. К построению типологии жанров социальных медиа // Жанры речи. № 2 (12). С. 119-127. URL: https:// cyberleninka.ru/article/n/k-postroeniyutipologii-zhanrov-sotsialnyh-mediy-1 (дата обращения: 04.01.2021).

Давлетшина С. Р., 2017. «Новые медиа» и тенденции развития мультимедийных жанров // Актуальные вопросы современной филологии и журналистики. № 2 (25). С. 86-92. URL: https://cyberleninka.ru/article/n/novye-media-itendentsii-razvitiya-multimediynyh-zhanrov (дата обращения: 04.01.2021).

Дадаева Т. М., Сновальникова У. А., 2019. Отражение социальных проблем в новых медиа (на при- 
мере видеоблога YouTube-канала TrashSmash) // Огарёв-Online. № 9 (130). C. 1-9. URL: https:// cyberleninka.ru/article/n/otrazhenie-sotsialnyhproblem-v-novyh-media-na-primere-videoblogayoutube-kanala-trashsmash (дата обращения: 04.01.2021).

Ковалев Л. А., 2016. Игровые форматы медиа: типы и жанры // Журналистский ежегодник. № 5. C. 96-97. URL: https://cyberleninka.ru/article/n/ igrovye-formaty-media-tipy-i-zhanry (дата обращения: 04.01.2021).

Колесниченко А. В., 2019. Востребованность жанров журналистских текстов аудиторией онлайновых медиа // Вестник Московского университета. Серия 10, Журналистика. № 3. C. 3-22. URL: https://cyberleninka.ru/article/n/ vostrebovannost-zhanrov-zhurnalistskihtekstov-auditoriey-onlaynovyh-media (дата обращения: 04.01.2021).

Корецкий М. Д., 2020. Трансформация телевизионных жанров на площадке YouTube на примере деятельности Алексея Пивоварова // Медиасреда. № 1. C. 41-44. URL: https:// cyberleninka.ru/article/n/transformatsiyatelevizionnyh-zhanrov-na-ploschadke-youtubena-primere-deyatelnosti-alekseya-pivovarova (дата обращения: 04.01.2021).

Лущиков В. А., Терских М. В., 2018а. Видеоблогинг как инструмент социальной коммуникации // Вестник Тамбовского университета. Серия: Общественные науки. Т. 4, № 13. C. 47-56. URL: https://cyberleninka.ru/article/ $\mathrm{n}$ /videobloging-kak-instrument-sotsialnoykommunikatsii (дата обращения: 04.01.2021).

Лущиков В. А., Терских М. В., 2018б. Жанрово-тематические и языковые особенности видеоблогов // Вестник Тамбовского университета. Серия: Общественные науки. № 14. C. 57-75. URL: https://cyberleninka.ru/article/n/ zhanrovo-tematicheskie-i-yazykovyeosobennosti-videoblogov (дата обращения: 04.01.2021).

Москвин А. С., Полуян Н. Н., Кушова И. А., 2017. Современная молодежная среда: виртуальный дауншифтинг в повседневной деятельности (на примере молодежи г. Кирова) // Теория и практика общественного развития. № 8 . C. 1-5. URL: https://cyberleninka.ru/article/n/ sovremennaya-molodezhnaya-sredavirtualnyy-daunshifting-v-povsednevnoydeyatelnosti-na-primere-molodezhi-g-kirova (дата обращения: 04.01.2021).

Панюкова С. А., 2018. Научно-популярный сторителлинг на YouTube-канале // Знак: проблемное поле медиаобразования. № 1. С. 122-127. URL: https://cyberleninka.ru/article/n/nauchno- populyarnyy-storitelling-na-youtube-kanale (дата обращения: 04.01.2021).

Сергеева О. В., Зиновьева Н. А., 2020. Публичные арены игровых стримов (на примере репрезентации темы коронавируса) // Социология власти. Т. 32, № 3. С. 221-241. URL: https:// cyberleninka.ru/article/n/publichnye-arenyigrovyh-strimov-na-primere-reprezentatsii-temykoronavirusa (дата обращения: 04.01.2021).

Сирмаи Э., 2019. «Много здесь, кто в стриме...». Распространение социальных медиа и девальвация основных средств массовой информации в Венгрии // Мониторинг общественного мнения: экономические и социальные перемены. № 5. C. 270-299. URL: https:// cyberleninka.ru/article/n/mnogo-zdes-kto-vstrime-rasprostranenie-sotsialnyh-media-idevalvatsiya-osnovnyh-sredstv-massovoyinformatsii-v-vengrii (дата обращения: 04.01.2021).

Текутьева И. А., 2016. Жанрово-тематическая классификация видеоблогинга // Медиасреда. № 11. C. 107-113. URL: https://cyberleninka.ru/ article/n/zhanrovo-tematicheskayaklassifikatsiya-videobloginga (дата обращения: 04.01.2021).

Финадеева М. В., 2008. Медиа-жанр: предпосылки когнитивного подхода // Мир науки, культуры, образования. № 2. С. 62-66. URL: https:// cyberleninka.ru/article/n/media-zhanrpredposylki-kognitivnogo-podhoda (дата обращения: 04.01.2021).

Чернявская В. Е., 2003. От анализа текста к анализу дискурса: немецкая школа дискурсивного анализа // Филологичекие науки. № 3. С. 68-76.

Шестерина А. М., 2020. Модификация архетипических сюжетов в современных аудиовизуальных медиа // Вопросы журналистики, педагогики, языкознания. № 2. C. 169-177. URL: https:// cyberleninka.ru/article/n/modifikatsiyaarhetipicheskih-syuzhetov-v-sovremennyhaudiovizualnyh-media (дата обращения: 04.01.2021).

Шмелева Т. В., 1997. Модель речевого жанра // Жанры речи. Саратов : Гос. учеб.-науч. центр «Колледж». С. 88-98.

\section{ИСТОЧНИКИ}

Венедиктов, 2020 - Венедиктов А. А. «\#дайДудя». 04.03.2020. URL: https://www.youtube.com/ watch?v=58Gx3crFwKU (дата обращения: 10.01.2021).

Венедиктов, 2021 - Венедиктов А. А. «\#дайДудя». 06.01.2021. URL: https://www.youtube.com/ 
watch?v=8ksikIeyWG0 (дата обращения: 10.01.2021).

\section{REFERENCES}

Alimov A.A., 2018. Kak khobbi stanovitsya v kreativnoy ekonomike rabotoy [How a hobby becomes a yob in the creative economy]. Ekonomicheskaya sociologiya [Economic sociology], vol. 19, no. 3, pp. 79-105. URL: https:// cyberleninka.ru/article/n/kak-hobbistanovitsya-v-kreativnoy-ekonomike-rabotoy (accessed 4 January 2021).

Bolotnov A.V., 2015a. Tekstovaya deyatelnost kak otrazhenie kommunikativnogo i kognitivnogo stiley informatsionno-mediynoy yazykovoy lichnosti [Textual activity of informational and media language personality as a reflection of its communicative and cognitive styles]. Tomsk, Tomsk CNTI Publ. 274 p.

Bolotnov A.V., 2015b. Tretichnye mediateksty kak otrazhenie informactsionnogo ekha [Tertiary media texts as a reflection of information echo]. Vestnik Tomskogo gosudarstvennogo pedagogicheskogo universiteta [Tomsk state pedagogical university bulletin], iss. 6(156), pp. 138-142.

Bolotnov A.V., 2016. Informatsionno-mediynaya yazykovaya lichnost nablyudatelya (svidetelya) i ee diskursivnye praktiki [Information and media linguistic personality of the observer (witness) and its discursive practices]. Vestnik Tomskogo gosudarstvennogo pedagogicheskogo universiteta [Tomsk state pedagogical university bulletin], iss. 11 (176), pp. 35-41.

Bolycheva M.D., 2018. Strimingovoe veshchanie kak fenomen sovremennoy mediasredy [Streaming broadcasting as a phenomenon of the modern media environment]. Kommunikologiya [Communicology], vol. 6, no. 4, pp. 159-169. URL: https://cyberleninka.ru/article/n/strimingovoeveschanie-kak-fenomen-sovremennoymediasredy (accessed 4 January 2021).

VolfO.A., 2020. Tradictsi zhurnalistskikh zhanrov vnovykh media (na primere pryamogo efira, rekomendatsii i eksperimenta) [Traditions of journalistic genres in new media (on the example of live broadcast, recommendations and experiment)]. Vestnik Khakasskogo gosudarstvennogo universiteta im. N.F. Kafanova, no. 2, pp. 68-72. URL: https:// cyberleninka.ru/article/n/traditsii-zhurnalistskihzhanrov-v-novyh-media-na-primere-pryamogoefira-rekomendatsii-i-eksperimenta (accessed 4 January2021).

Goroshko E.I., Polyakova T.L., 2015. K postroeniyu tipologii zhanrov socialnykh media [Towards a typology of social media genres]. Zhanry rechi [Speech genres], no. 2 (12), pp. 119-127. URL: https://cyberleninka.ru/article/n/k-postroeniyutipologii-zhanrov-sotsialnyh-mediy-1 (accessed 4 January 2021).

Davletshina S.R., 2017. «Novye media» i tendentsii razvitiya multimediynykh zhanrov ["New media" and trends in the development of multimedia genres]. Aktualnye voprosy sovremennoy filologii i zhurnalistiki [Actual problems of modern philology and journalism], no. 2 (25), pp. 86-92. URL: https://cyberleninka.ru/article/ n/novye-media-i-ten dentsii-razvitiyamultimediynyh-zhanrov (accessed 4 January 2021).

Dadaeva T.M., Snovalnikova U.A., 2019. Otrazhenie socialnykh problem v novykh media (na primere videobloga YouTube-kanala TrashSmash) [Reflection of social problems in new media (for example, the video blog of the YouTube channel TrashSmash)]. Ogaryov-Online, no. 9 (130), pp. 1-9. URL: https://cyberleninka.ru/article/n/ otrazhenie-sotsialnyh-problem-v-novyh-mediana-primere-videobloga-youtube-kanalatrashsmash (accessed 4 January 2021).

Kovalev L.A., 2016. Igrovye formaty media: tipy i zhanry [Game media formats: types and genres]. Zhurnalistskiy ezhegodnik [Journalistic Yearbook], no. 5, pp. 96-97. URL: https:// cyberleninka.ru/article/n/igrovye-formatymedia-tipy-i-zhanry (accessed 4 January 2021).

Kolesnichenko A.V., 2019. Vostrebovannost zhanrov zhurnalistskikh tekstov auditoriey onlaynovykh media [Demand for genres of yournalistic texts by the audience of online media]. Vestnik Moskovskogo universiteta. Seriya 10. Zhurnalistika, no. 3, pp. 3-22. URL: https:// cyberleninka.ru/article/n/vostrebovannostzhanrov-zhurnalistskih-tekstov-auditorieyonlaynovyh-media (accessed 4 January 2021).

Koreckiy M.D., 2020. Transformatsiya televizionnykh zhanrov na ploshchadke YouTube na primere deyatelnosti Alekseya Pivovarova [Transformation of TV genres on the YouTube site on the example of the activities of Alexei Pivovarov]. Mediasreda [Media sphere], no. 1, pp. 41-44. URL: https://cyberleninka.ru/article/ n/transformatsiya-televizionnyh-zhanrov-naploschadke-youtube-na-primere-deyatelnostialekseya-pivovarova (accessed 4 January 2021).

Lushchikov V.A., Terskikh M.V., 2018a Videobloging kak instrument socialnoy kommunikatsii [Video blogging as a tool of social communication]. Vestnik Tambovskogo universiteta. Seriya: Obshhestvennye nauki [Tambov University Review. Series Social Sciences], vol. 4, no. 13, 
pp. 47-56. URL: https:/cyberleninka.ru/article/ n/videobloging-kak-instrument-sotsialnoykommunikatsii (accessed 4 January 2021).

Lushchikov V.A., Terskikh M.V., 2018b. Zhanrovotematicheskie i yazykovye osobennosti videoblogov [Genre-thematic and linguistic features of video blogs]. Vestnik Tambovskogo universiteta. Seriya: Obshhestvennye nauki [Tambov University Review. Series Social Sciences], no. 14, pp. 57-75. URL: https:// cyberleninka.ru/article/n/zhanrovotematicheskie-i-yazykovye-osobennostivideoblogov (accessed 4 January 2021).

Moskvin A.S., Poluyan N.N., Kushova I.A., 2017. Sovremennaya molodezhnaya sreda: virtualnyy daunshifting $\mathrm{v}$ povsednevnoy deyatelnosti (na primere molodezhi g. Kirova) [Modern youth environment: virtual downshifting in everyday activities (on the example of young people in Kirov)]. Teoriya i praktika obshchestvennogo razvitiya [Theory and practice of social development], no. 8, pp. 1-5. URL: https:// cyberleninka.ru/article/n/sovremennayamolodezhnaya-sreda-virtualnyy-daunshiftingv-povsednevnoy-deyatelnosti-na-primeremolodezhi-g-kirova (accessed 4 January 2021).

Panyukova S.A., 2018. Nauchno-populyarnyy storitelling na YouTube-kanale [Popular science storytelling on the YouTube channel]. Znak: problemnoe pole mediaobrazovaniya [Sign: the problem field of media education], no. 1, pp. 122127. URL: https://cyberleninka.ru/article/n/ nauchno-populyarnyy-storitelling-na-youtubekanale (accessed 4 January 2021).

Sergeeva O.V., Zinoveva N.A., 2020. Publichnye areny igrovykh strimov (na primere reprezentatsii temy koronavirusa) [Public arenas of game streams (on the example of the representation of the coronavirus theme)]. Sociologiya vlasti [Sociology of Power], vol. 32, no. 3, pp. 221-241. URL: https://cyberleninka.ru/article/n/ publichnye-areny-igrovyh-strimov-na-primerereprezentatsii-temy-koronavirusa (accessed 4 January 2021).

Szirmai E., 2019. «Mnogo zdes, kto v strime...». Rasprostranenie sotsialnykh media i devalvactsiya osnovnykh sredstv massovoy informatsii v Vengrii ["Many are live round here." The spread of social media and the devaluation of mainstream media in Hungary]. Monitoring obshhestvennogo mneniya: ekonomicheskie $i$ socialnye peremeny [Monitoring of public opinion: economic and social changes], no. 5, pp. 270-299. URL: https://cyberleninka.ru/article/ n/mnogo-zdes-kto-v-strime-rasprostraneniesotsialnyh-media-i-devalvatsiya-osnovnyhsredstv-massovoy-in formatsii-v-vengrii (accessed 4 January 2021).

Tekuteva I.A., 2016. Zhanrovo-tematicheskaya klassifikatsiya videobloginga [Genre-thematic classification of video blogging]. Mediasreda [Media sphere], no. 11, pp. 107-113. URL: https:/ /cyberleninka.ru/article/n/zhanrovotematicheskaya-klassifikatsiya-videobloginga (accessed 4 January 2021).

Finadeeva M.V., 2008. Media-zhanr: predposylki kognitivnogo podkhoda [Media genre: preconditions of the cognitive approach]. Mir nauki, kultury, obrazovaniya [World of science, culture, education], no. 2, pp. 62-66. URL: https:// cyberleninka.ru/article/n/media-zhanrpredposylki-kognitivnogo-podhoda (accessed 4 January 2021).

Chernyavskaya V.E., 2003. Ot analiza teksta $\mathrm{k}$ analizu diskursa: nemetskaya shkola diskursivnogo analiza [From text analysis to discourse analysis: the German school of discourse analysis]. Filologichekie nauki [Philological sciences], no. 3, pp. 68-76.

Shesterina A.M., 2020. Modifikatsiya arkhetipicheskikh syuzhetov v sovremennykh audiovizualnykh media [Modification of archetypal plots in modern audiovisual media]. Voprosy zhurnalistiki, pedagogiki, yazykoznaniya [Issues in Journalism, Education, Linguistics], no. 2, pp. 169-177. URL: https://cyberleninka.ru/article/n/ modifikatsiya-arhetipicheskih-syuzhetov-vsovremen nyh-audiovizualnyh-media (accessed 4 January 2021).

Shmeleva T.V., 1997. Model rechevogo zhanra [Speech genre model]. Zhanry rechi [Speech genres]. Saratov, Gosudarstvennyy uchebno-nauchnyy tsentr "Kolledzh", pp. 88-98.

\section{SOURCES}

Venediktov A.A. «\#dayDudya». 04.03.2020. URL: https://www.youtube.com/watch? $\mathrm{v}=58 \mathrm{Gx} 3 \mathrm{crFwKU}$ (accessed 10 January 2021).

Venediktov A.A. «\#dayDudya». 06.01.2021. URL: https://www.youtube.com/watch?v=8ksikIeyWG0 (accessed 10 January 2021). 


\section{НОВЫЕ АСПЕКТЫ ИЗУЧЕНИЯ ЖАНРОВ И ТИПОВ ТЕКСТОВ}

\section{Information About the Author}

Aleksey V. Bolotnov, Doctor of Sciences (Philology), Professor, Department of the Russian language, Tomsk State Pedagogical University, Kievskaya St, 60, 634061 Tomsk, Russia, _avb_@sidmail.com, https://orcid.org/0000-0001-7442-9115

\section{Информация об авторе}

Алексей Владимирович Болотнов, доктор филологических наук, профессор кафедры русского языка, Томский государственный педагогический университет, ул. Киевская, 60, 634061 г. Томск, Россия,_avb_@sidmail.com, https://orcid.org/0000-0001-7442-9115 